\title{
DETERMINATION OF SEASONAL FACTORS FOR STRUCTURAL CONDITION VALUES OF BITUMINOUS PAVEMENTS
}

\author{
Virgaudas Puodžiukas', Algis Pakalnis ${ }^{2}$ \\ 'Lithuanian Road Administration, J. Basanavičiaus 36/2,LT-2009 Vilnius, Lithuania.E-mail: vpuodziukas@lra.lt \\ ${ }^{2}$ Transport and Road Research Institute, I. Kanto 25, LT-3000 Kaunas, Lithuania. E-mail: a.pakalnis@tkti.lt
}

Received 20 Febr 2001; accepted 05 Febr 2002

\begin{abstract}
This article studies the effect of each season on the structural condition values of bituminous pavements. Testing of bituminous pavements was carried out by the falling-weight deflectometer DYNATEST 8000 FWD. The following values of pavement strength were used: the equivalent resilient modulus of the road pavement Eekv; deformation modulus of the roadbed soil Eg; pavement structural number SN; subgrade structural number SNSG; a modified structural number SNC. In the process of work the structural condition values of spring and autumn were determined and a statistical analysis of these values was presented. The analysis of the three-year research results showed that in spring the pavement condition weakens in respect of all criteria of pavement structural condition. Therefore, for the future analysis only the structural condition values of spring are suggested to be used. The article gives also the critical period adjustment factors for each structural condition value on the selected test road sections with different pavement structure. The article gives recommendations for the practical use of research results.
\end{abstract}

Keywords: falling-weight deflectometer, non-destructive testing, statistical analysis, pavement, structural number.

\section{Introduction}

When planning road maintenance actions it is very important to collect information necessary for evaluating the road pavement structure. At present Lithuania has $80000 \mathrm{~km}$ of roads. State-owned roads $(21312 \mathrm{~km})$ are managed and maintained by the Lithuanian Road Administration. A major part of them $(11100 \mathrm{~km})$ includes roads with bituminous pavement [1].

Road pavement is one of the most important road elements. Static and dynamic transport loads and environmental factors continuously affect it. The effect of traffic and environment causes variations in the physical and mechanical properties of roadbed soils and structural pavement layers [2-4].

Spring and winter are the periods for the most critical conditions when, under the effect of frost, pavement materials become brittle while in the period of thawing they exhibit plastic properties due to increased moisture. An especially unfavourable situation may occur in spring when the unbound layers of pavement structure still keep the accumulated excess of moisture and asphalt concrete pavement warms up $[5,6]$.

The strength of asphalt concrete pavements on Lithuanian state roads has approximately decreased by $2 \%$ per annum. Strengthening road pavements should be effective, comply with pavement condition and climatic conditions [7].
In order to preserve a satisfactory condition of roads in the situation of insufficient financing the Lithuanian Pavement Management System DAVASEMA has been used since 1997 . The strength of bituminous road pavements is determined by the deflectometer DYNATEST $8000 \mathrm{FWD}$. In the same year a research program was started aiming at determining the effect of environment and traffic on the durability of bituminous pavements and ensuring reliability of the FWD results under Lithuanian conditions [7].

\section{Deflection measurements}

Dynamic deflections of the road pavement were measured by the falling-weight deflectometer Dynatest 8000 FWD [2]. Measurements were taken on both traffic lanes of each test section (a total of 23 test sections) by measuring deflections on two test points of each traffic lane (four points on each test section). During testing the load of $40 \mathrm{kN}$ is applied on the road pavement. Deflections are recorded by 9 sensors (geophones). Spacing of sensors from the centre of the loading plate are: $0,200,300,450,600,900,1200,1500,1800 \mathrm{~mm}$. On each test point 5 measurements were taken. The average number of 14 measurements were taken annually on each test section. The schedule of testing was based on different climatic conditions (in summer - once per month, during spring thaw - once per week, no measurements 
were carried out in winter time). When measuring deflections the bituminous pavement temperature was also measured. Deflection measurements on test road sections has been carried out since June 1997.

\section{Calculation of deflection measurement data}

All the measurement data were calculated after it had been determined that the relationship between deflection and loading is linear [3]. Deflection values were calculated at $708 \mathrm{kPa}$ pressure, corresponding to the load of $50 \mathrm{kN}$.

The average pavement temperature is used to determine a temperature adjustment factor, required for calculating pavement deflection values at an assumed reference temperature of $20^{\circ} \mathrm{C}[4,8]$. The average pavement temperature is measured by an electronic thermometer TE-100. The depth where the average temperature of bituminous pavement layers is measured equals half the thickness of bituminous pavement layers. The pavement temperature is measured in a drilled out bore-hole.

The temperature adjustment factor gives the opportunity to correct the deflection obtained at any temperature into the deflection at a reference temperature $\left(20^{\circ} \mathrm{C}\right)$. The diagram of adjustment factors is given in Fig 1 [2].

The temperature adjustment factor could be described by an empirical relationship obtained from the diagram of adjustment factors:

$k_{T}=\left(-0.0027 * h_{a / b}+1.063\right) e^{\left(0.0002^{*} h_{a / b}-0.0065\right) T_{d}}$

where $k_{T}$ is the temperature adjustment factor; $T_{d}$ is mean bituminous pavement temperature, ${ }^{\circ} \mathrm{C} ; h_{a / b}$ is thickness of bituminous pavement layer, $\mathrm{mm}$.

All the calculations are carried out for the load of $50 \mathrm{kN}$, taking the temperature adjustment factor into account.

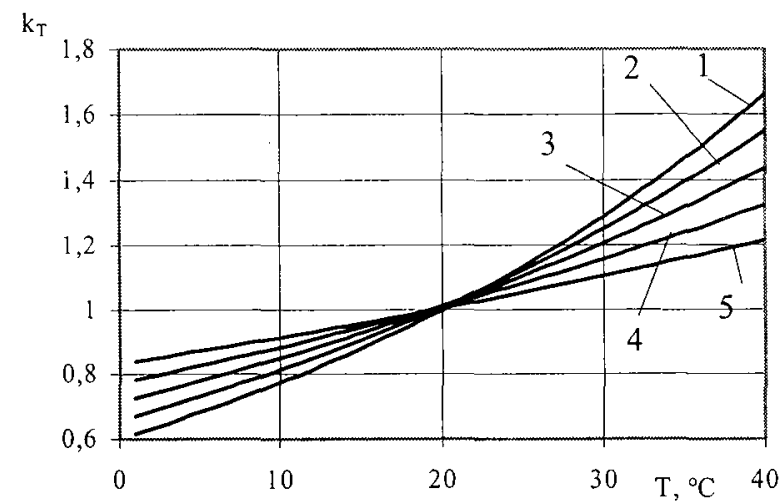

Fig 1. Relationship between the temperature adjustment factor and bituminous pavement temperature $\left(1-\mathrm{h}_{\mathrm{a} / \mathrm{b}}=\right.$ $160 \mathrm{~mm} ; 2-\mathrm{h}_{\mathrm{a} / \mathrm{b}}=140 \mathrm{~mm} ; 3-\mathrm{h}_{\mathrm{a} / \mathrm{b}}=120 \mathrm{~mm} ; 4-\mathrm{h}_{\mathrm{a} /}$ $\mathrm{h}=110 \mathrm{~mm} ; 5-\mathrm{h}_{\mathrm{a} / \mathrm{h}}=100 \mathrm{~mm}$;) at different thicknesses of bituminous pavement layer

\section{Factors of the road pavement structural condition}

Based on the method selected, various factors could be used for evaluating and comparing structural condition of the road pavement. The current Lithuanian Road Design Codes and Regulations PNT-K 95 [9] are regulating the modulus of stiffness on the surface of different structural pavement base layers. When using a worldwide AASHTO design method $[10,11]$, road pavement structural condition is characterised by the following factors: SN (Structural Number of the Pavement), SNSG (Structural Number contribution from the subgrade) and SNC (Modified Structural Number).

The equivalent resilient modulus of road pavement structure $\left(\mathrm{E}_{\text {ekv }}\right)$ and deformation modulus of roadbed soil $\left(E_{\mathrm{o}}\right)$. Calculations were carried out by using ELMOD software (Evaluation of Layer Moduli and Overlay Design) designed by the DYNATEST. The software enables to calculate resilient modulus of each layer in the pavement structure of two, three or four layers by using Odemark-Boussinesq transformed cross-sectional method [8]. To calculate the resilient modulus for a four-layer pavement structure it is necessary either to know the ratio between the modulus of the second and the third layer or to calculate it by using the above-mentioned software from thickness of the second and the third layer. In the latter case a relationship developed by Dormon and Metcalf is used [5]:

$$
\frac{E_{n}}{E_{n-1}}=0.2 h_{n}^{0.45},
$$

where $E_{n}$ is the modulus of the upper layer with thickness $h_{n} ; E_{n-1}$ is the modulus of the lower layer.

In calculating the resilient modulus from the deflections, the layer thickness should be not less than $80 \mathrm{~mm}$, therefore thinner layers should be joined together. Bituminous pavement resilient modulus depends merely on the temperature; seasonal variations are not taken into account. The equivalent road pavement resilient modulus $\mathrm{E}_{\mathrm{ekv}}$ is calculated from the following formula [12]:

$$
E_{e k v}=\frac{2\left(1-\mu^{2}\right) q a}{D_{0}},
$$

where $\mu$ is Poisson's ratio; $q$ is pavement pressure by a measuring device $(\mathrm{kPa}) ; a$ is the radius of the loading plate $(\mathrm{mm}) ; D_{0}$ is the centre deflection $(\mu \mathrm{m})$.

The roadbed soil deformation modulus $E_{g}$ is calculated by the method, presented in reference [8]:

$$
E_{g}=\frac{\left(1-\mu^{2}\right) q a^{2}}{r \times D(r)},
$$

where $r$ is the distance from the load centre $(\mathrm{mm}) ; D(r)$ is deflection at a distance $r$ from the load axis $(\mu \mathrm{m})$.

A modified structural number of road pavement (SNC):

$$
S N C=S N+S N S G
$$


The structural number of all pavement layers (SN) is determined by the relationship developed by G. W. Jameson [2]:

$$
S N=1.69+\frac{842.8}{D_{0}-D_{1500}}+\frac{42.94}{D_{900}} .
$$

$$
S N S G=3.51 \log (C B R)-0.85(\log (C B R))^{2}-1.43 \text {, }
$$

where $\log (C B R)=3.264-1.018 \log \left(D_{900}\right)$; CBR is California Bearing Ratio.

\section{Calculation of the changes in structural condition due to seasonal factors}

The decrease in pavement structural condition on each test section due to seasonal factors (ie critical period adjustment factors) is calculated by the algorithm, the scheme of which is shown in Fig 2.

The maximum and minimum values of pavement structural condition were determined during the threeyear research on each test section $[1,6,7]$.

The seasonal factors were determined according to the data of a specific year of research. The following values of pavement strength were used [13]:

- the equivalent resilient modulus of the road pavement $\mathrm{E}_{\mathrm{ekv}}$;

Table 1. Seasonal factors based on three-year research results

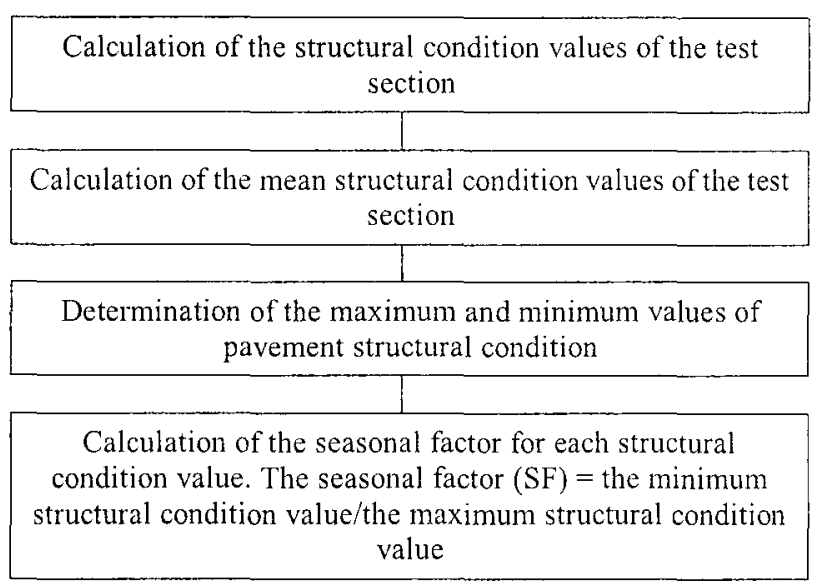

Fig 2. The scheme of the seasonal factor calcula

- deformation modulus of the roadbed soil $\mathrm{E}_{\mathrm{g}}$;

- pavement structural number SN;

- subgrade structural number SNSG;

- a modified structural number SNC.

Seasonal factors based on the three-year research results are presented in Table 1.

In the course of work the structural condition values of spring and autumn were determined. A statistical

\begin{tabular}{|c|c|c|c|c|c|c|c|c|c|c|c|c|c|c|c|}
\hline \multirow{3}{*}{$\begin{array}{c}\text { Test section, } \\
\mathrm{km}\end{array}$} & \multicolumn{15}{|c|}{ Seasonal factors } \\
\hline & \multicolumn{3}{|c|}{$\mathrm{K}_{\text {Eekv }}$} & \multicolumn{3}{|c|}{$\mathrm{K}_{\mathrm{Eg}}$} & \multicolumn{3}{|c|}{$\mathrm{K}_{\mathrm{SN}}$} & \multicolumn{3}{|c|}{$\mathrm{K}_{\mathrm{SNSG}}$} & \multicolumn{3}{|c|}{$\mathrm{K}_{\mathrm{SNC}}$} \\
\hline & $1^{*}$ & 2 & 3 & 1 & 2 & 3 & 1 & 2 & 3 & 1 & 2 & 3 & 1 & 2 & 3 \\
\hline \multicolumn{16}{|c|}{ Road A5 Kaunas - Marijampole - Suvalkai } \\
\hline $35.2-35.5$ & 0.81 & 0.71 & 0.74 & 0.95 & 0.91 & 0.82 & 0.84 & 0.73 & 0.74 & 0.97 & 0.94 & 0.87 & 0.88 & 0.79 & 0.80 \\
\hline $19.0-19.3$ & 0.79 & 0.70 & 0.68 & 0.96 & 0.81 & 0.90 & 0.87 & 0.81 & 0.77 & 0.99 & 0.89 & 0.96 & 0.91 & 0.84 & 0.82 \\
\hline \multicolumn{16}{|c|}{ Road A6 Kaunas - Zarasai - Daugpilis } \\
\hline $15.3-15.6$ & 0.45 & 0.65 & 0.53 & 0.83 & 0.88 & 0.82 & 0.64 & 0.80 & 0.70 & 0.93 & 0.96 & 0.94 & 0.71 & 0.85 & 0.77 \\
\hline $16.8-17.1$ & 0.49 & 0.66 & 0.54 & 0.76 & 0.85 & 0.80 & 0.69 & 0.81 & 0.74 & 0.93 & 0.96 & 0.96 & 0.75 & 0.85 & 0.80 \\
\hline $32.7-33.0$ & 0.69 & 0.83 & 0.84 & 0.81 & 0.82 & 0.84 & 0.78 & 0.88 & 0.88 & 0.81 & 0.92 & 0.94 & 0.83 & 0.89 & 0.90 \\
\hline $34.5-34.8$ & 0.76 & 0.80 & 0.82 & 0.54 & 0.72 & 0.75 & 0.83 & 0.84 & 0.87 & 0.78 & 0.90 & 0.92 & 0.87 & 0.88 & 0.88 \\
\hline \multicolumn{16}{|c|}{ Road A8 Panevèžys - Kèdainiai - Cinkiškiai } \\
\hline $26.7-27.0$ & 0.81 & 0.71 & 0.70 & 0.86 & 0.84 & 0.78 & 0.87 & 0.80 & 0.73 & 0.93 & 0.93 & 0.92 & 0.89 & 0.84 & 0.77 \\
\hline $32.2-32.5$ & 0.66 & 0.67 & 0.68 & 0.84 & 0.85 & 0.81 & 0.76 & 0.76 & 0.77 & 0.92 & 0.90 & 0.91 & 0.80 & 0.80 & 0.80 \\
\hline \multicolumn{16}{|c|}{ Road 208 Southeast Utena by - pass } \\
\hline $0.1-0.4$ & 0.49 & 0.71 & 0.57 & 0.84 & 0.74 & 0.81 & 0.72 & 0.84 & 0.74 & 0.88 & 0.88 & 0.93 & 0.77 & 0.87 & 0.79 \\
\hline $1.5-1.8$ & 0.42 & 0.66 & 0.42 & 0.79 & 0.83 & 0.79 & 0.70 & 0.82 & 0.70 & 0.83 & 0.87 & 0.83 & 0.74 & 0.83 & 0.74 \\
\hline \multicolumn{16}{|c|}{ Road A17 Panevezžys by - pass } \\
\hline $9.9-10.2$ & 0.74 & 0.77 & 0.70 & 0.83 & 0.76 & 0.72 & 0.83 & 0.84 & 0.79 & 0.90 & 0.92 & 0.91 & 0.86 & 0.87 & 0.82 \\
\hline $7.9-8.2$ & 0.79 & 0.81 & 0.74 & 0.78 & 0.79 & 0.70 & 0.85 & 0.85 & 0.81 & 0.91 & 0.94 & 0.92 & 0.87 & 0.88 & 0.84 \\
\hline $7.2-7.5$ & 0.79 & 0.81 & 0.74 & 0.81 & 0.77 & 0.73 & 0.85 & 0.84 & 0.80 & 0.93 & 0.94 & 0.93 & 0.87 & 0.87 & 0.83 \\
\hline
\end{tabular}
analysis of the values is given in Tables 2 and 3 . The

* $1,2,3$ refers to the year of research 
Table 2. The results of statistical analysis of spring factors

\begin{tabular}{|c|c|c|c|c|c|c|c|c|}
\hline \multirow{2}{*}{ Factor } & \multirow{2}{*}{ The average } & \multicolumn{2}{|c|}{ The range of reliability } & \multirow{2}{*}{ Median } & \multirow{2}{*}{ Minimum } & \multirow{2}{*}{ Maximum } & \multirow{2}{*}{$\begin{array}{l}\text { Variation } \\
\text { factor }\end{array}$} & \multirow{2}{*}{$\begin{array}{l}\text { Standard } \\
\text { deviation }\end{array}$} \\
\hline & & -0.05 & +0.05 & & & & & \\
\hline $\mathrm{K}_{\text {Eekv }}$ & 0.69 & 0.67 & 0.72 & 0.70 & 0.42 & 0.94 & 0.012 & 0.11 \\
\hline $\mathrm{K}_{\mathrm{Eg}}$ & 0.81 & 0.80 & 0.83 & 0.82 & 0.54 & 0.96 & 0.005 & 0.07 \\
\hline $\mathrm{K}_{\mathrm{SN}}$ & 0.79 & 0.78 & 0.81 & 0.80 & 0.61 & 0.95 & 0.005 & 0.07 \\
\hline $\mathrm{K}_{\text {SNSG }}$ & 0.91 & 0.90 & 0.92 & 0.92 & 0.77 & 0.99 & 0.002 & 0.04 \\
\hline $\mathrm{K}_{\mathrm{SNC}}$ & 0.83 & 0.82 & 0.84 & 0.83 & 0.68 & 0.96 & 0.003 & 0.06 \\
\hline
\end{tabular}

Table 3. The results of statistical analysis of autumn factors

\begin{tabular}{|c|c|c|c|c|c|c|c|c|}
\hline \multirow{2}{*}{ Factor } & \multirow{2}{*}{ The average } & \multicolumn{2}{|c|}{ The range of reliability } & \multirow{2}{*}{ Median } & \multirow{2}{*}{ Minimum } & \multirow{2}{*}{ Maximum } & \multirow{2}{*}{$\begin{array}{l}\text { Variation } \\
\text { factor }\end{array}$} & \multirow{2}{*}{$\begin{array}{l}\text { Standard } \\
\text { deviation }\end{array}$} \\
\hline & & -0.05 & +0.05 & & & & & \\
\hline $\mathrm{K}_{\text {Eekv }}$ & 0.77 & 0.74 & 0.79 & 0.77 & 0.45 & 0.97 & 0.013 & 0.11 \\
\hline $\mathrm{K}_{\mathrm{Eg}}$ & 0.88 & 0.86 & 0.89 & 0.87 & 0.76 & 0.98 & 0.004 & 0.06 \\
\hline $\mathrm{K}_{\mathrm{SN}}$ & 0.84 & 0.82 & 0.86 & 0.85 & 0.65 & 0.97 & 0.005 & 0.07 \\
\hline $\mathrm{K}_{\text {SNSG }}$ & 0.94 & 0.93 & 0.95 & 0.95 & 0.81 & 0.99 & 0.001 & 0.03 \\
\hline$\overline{K_{\text {SNC }}}$ & 0.87 & 0.85 & 0.88 & 0.87 & 0.72 & 0.98 & 0.004 & 0.06 \\
\hline
\end{tabular}

tables show that in spring pavement condition weakens in respect of all criteria of pavement strength, therefore, only the structural condition values of spring were used for further analysis.

The means values of seasonal factors and standard deviations determined for different pavement condition values are given in Fig 3.

\section{Conclusions}

1. Deflection measurements by the falling-weight deflectometer DYNATEST 8000 FWD and calculations of resilient modulus of pavement layers allow to determine the structural condition of the existing pavement.

2. The seasonal tests of pavement deflections show that:

- under Lithuanian conditions the critical period for pavements is March - April, when the frozen ice crystals thaws in the roadbed;

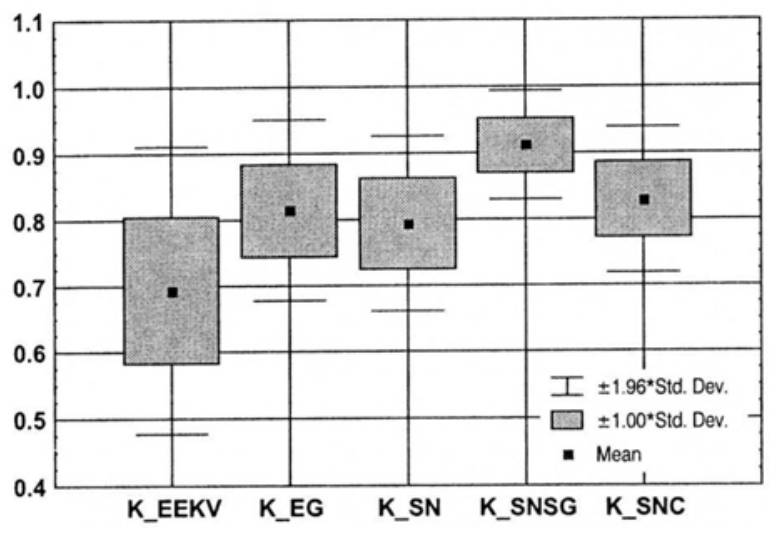

Fig 3. The mean values and standard deviations of seasonal factors
- a stable period of pavement structural condition is usually observed in a summer period (June August);

- the calculated seasonal factors for $\mathrm{E}_{\mathrm{ekv}}, \mathrm{E}_{\mathrm{g}}, \mathrm{SN}$, SNSG, SNC are different.

3. Based on the three-year research results, the values of seasonal factors were determined for the abovementioned values, which are the difference between the average spring value and the value of standard deviation. The critical period adjustment factor for each pavement structural condition value is:

- for the equivalent resilient modulus of the road pavement $\mathrm{E}_{\text {ekv }}-0.58$;

- for deformation modulus of the roadbed soil $\mathrm{E}_{\mathrm{g}}$ - 0.74;

- for pavement structural number $\mathrm{SN}-0.73$;

- for subgrade structural number SNSG - 0.87;

- for a modified structural number of the road pavement SNC - 0.77 .

4. To select a proper and economically justified type of pavement strengthening, it is necessary:

- to determine the existing condition of pavement strength based on FWD data;

- to measure pavement deflections during the stable summer period, since the seasonal factors are calculated as a ratio between the value of strength factor during the most critical period and its value during the stable period;

- to calculate the critical resilient modulus of the existing pavement structure, when the thicknesses of structural pavement layers are known and the seasonal factors are taken into consideration;

- when calculating SN, SNSG and SNC used by Highway Development and Management Tools 
HDM-III, HDM-IV and the Lithuanian PMS DAVASEMA to take into account the seasonal factors. mended:

5. On the level of the road network it is recom-

- based on the current pavement quality data (roughness and results of visual inspections), to select a number of road sections for determining their pavement structural conditions;

- on the selected road sections, where pavement structural conditions are planned to be identified, pavement deflections shall be measured every $100 \mathrm{~m}$ on the right (outside) path of the traffic lane adjacent to the shoulder;

- according to deflection testing results to calculate the equivalent resilient modulus of road pavement structure $\mathrm{E}_{\mathrm{ekv}}$ and a modified structural number $\mathrm{SNC}$;

- data on the strength factors of the Lithuanian state road network shall be accumulated in a Lithuanian Road Data Bank.

6. Data on structural condition, followed by roughness (IRI) and visual inspection data enables the design organisations and road maintenance services to methodically determine condition of bituminous pavement pavements, to predict pavement deterioration and to determine the urgent measures for pavement management. In the process of design these data allow to select the optimal pavement structure and define the types of strengthening.

\section{References}

1. Kamaitis Z., Puodžiukas V. Asphalt Pavement Strengthening and Modelling its Effect on Pavement Roughness. Civil Engineering (Statyba), Vol V, No 6. Vilnius: Technika, 1999, p. 286-393.
2. Dynatest 8000 FWD Test System, Dynatest Engineering A/S, 1995. $256 \mathrm{p}$.

3. AASHTO Guide for Design of Pavement Structures. Washington: AASHTO, 1993. $324 \mathrm{p}$

4. Baltzer S., Jansen J. M. Temperature Correction of Asphalt - Moduli for FWD Measurements. In: Proc. of the $4^{\text {th }}$ International Conference on the Bearing Capacity of Roads and Airfields. Minnesota: University of Minnesota, 1994, Vol 1, p. 754-767.

5. Design Curves for Flexible Pavements Based on Layered System Theory, Highway Research Record, No 71, 1965. $67 \mathrm{p}$.

6. Puodžiukas V. Bituminous Pavement Evaluation and Strengthening Needs Assessement in Lithuania (Asfaltbetonio dangu būklès tyrimai ir stiprinimo poreikis Lietuvos keliuose): Summary of Doctoral Dissertation. Vilnius: Technika, 2000. $42 \mathrm{p}$.

7. Dimaitis M., Pakalnis A., Puodžiukas V. The use of Falling Weight Deflectometer for Evaluation of Road Pavement Strength in Lithuania. Transport (Transportas), Vol XIV, No 5, Vilnius: Technika, 1999, p. 215-219.

8. Per Ullidtz. Modelling Flexible Pavement Response and Performance. Polyteknisk Forlag, Gylling, 1998. 205 p.

9. Standards and Rules of Motorways Design PNT. K 95. Kaunas: Kelprojektas, 1996. 105 p. (in Lithuanian).

10. Modelling Road Deterioration and Maintenance Effects in HDM-4. RETA 5549 - REG Highway Development and Management Research Final Report. N. D. Lea International LTD, 1995. 397 p.

11. Pavement Notes for Design, Evaluation and Rehabilitation. WSDOT Pavement Guide. Washington State Department of Transportation, 1995. $681 \mathrm{p}$.

12. Pavement Design Based on Theory of Elasticity. Vejen: Phonix Pavement Consultants, 1993. $21 \mathrm{p}$

13. Puodžiukas V. Flexible Pavement Evaluation and Strengthening in Lithuania. In: Proceedings of the Fifth International Conference on the Bearing Capacity of Roads and Airfields. Trondheim, Norway, 1998, p. 1807-1816. 